\title{
PENGARUH GOOD CORPORATE GOVERNANCE (GCG) TERHADAP NILAI PERUSAHAAN PADA PERUSAHAAN MANUFAKTUR YANG TERDAFTAR DI BURSA EFEK INDONESIA TAHUN 2015-2017
}

\author{
Sutrisno, Ariyani Indriastuti \\ STIE SEMARANG \\ sutrisno@stiesemarang.ac.id
}

\begin{abstract}
All information in a company's financial statements is useful for investors and users of financial statements because the information contained in financial statements can be used by interested parties or users of financial statements for consideration in making economic decisions, but sometimes the attention of financial statement users or investors is only focused on earnings information. The purpose of this research is to find out. Effect of Good Corporate Governance managerial ownership of institutional ownership and the Audit Committee on Company Value in manufacturing companies listed on the Indonesia Stock Exchange 2015-2017. The population in this study are manufacturing companies listed on the Indonesia Stock Exchange (IDX) in 20152017. The companies that became the population in this study were 24 manufacturing companies. The variables in this study were managerial ownership, institutional ownership and an audit committee on Company Value. Methods of data analysis using multiple linear regression, coefficient of determination and hypothesis testing. The results of this study indicate that the managerial ownership regression coefficient is 0.304, tcount (3.847)> ttable (1.66) and sign $(0.000),<(0.05)$, institutional ownership is 0.337 , tcount (3.375)> table (1.66) and sign (0.001) $<(0.05)$ and audit committee 0.341 , tcount $(4.110)>$ ttable $(1.66)$ and sign $(0.000)<(0.05)$ based on the coefficient test results R2 determination of $62.8 \%$. This means managerial ownership of institutional ownership and audition committee. Together - they have a positive and significant effect on Company Value. This can be proven in the F test of 38,231 in manufacturing companies listed on the Indonesia Stock Exchange 2015-2017. Company value calculation using PBV (price book value) proxy. However, the calculation of company value can be done using other methods such as Tobin's Q because the calculation of company value does not only use PBV. Given the results of this study indicate that a positive effect on a corporate value of good corporate governance
\end{abstract}

Keywords: Good Corporate Governance and Company Value 


\begin{abstract}
ABSTRAK
Semua informasi dalam laporan keuangan suatu perusahaan merupakan hal yang bermanfaat bagi para investor maupun pengguna laporan keuangan karena informasi yang terdapat dalam laporan keuangan dapat digunakan pihak yang berkepentingan atau pemakai laporan keuangan sebagai pertimbangan dalam pengambilan keputusan ekonomi, namun terkadang perhatian pengguna laporan keuangan ataupun investor hanya terpusat pada informasi laba. Tujuan dalam penelitian ini adalah, untuk mengetahui. Pengaruh Good Corporate Governance kepemilikan manajerial kepemilikan institusional dan Komite Audit terhadap Nilai Perusahaan pada perusahaan manufaktur yang terdaftar di Bursa Efek Indonesia 2015-2017.

Populasi dalam penelitian ini adalah perusahaan manufaktur yang terdaftar di Bursa Efek Indonesia (BEI) tahun 2015-2017. Perusahaan yang menjadi populasi dalam penelitian ini adalah perusahaan manufaktur berjumlah 24. Variabel dalam penelitian ini yaitu kepemilikan manajerial kepemilikan institusional dan komite audit terhadap Nilai Perusahaan. Metode analisis data menggunakan regresi linier berganda, koefisien determinasi dan uji hipotesis.

Hasil dari penelitian ini adalah menunjukan dengan nilai koefesien regresi kepemilikan manajerial 0,304 , nilai $t_{\text {hitung }}(3,847)>t_{\text {tabel }}(1,66)$ dan sign $(0,000),<(0,05)$, kepemilikan institusional sebesar 0,337 , nilai thitung $(3,375)>t_{\text {tabel }}(1,66)$ dan sign $(0,001)<(0,05)$ dan komite audit sebesar 0,341 , nilai thitung $(4,110)>t_{\text {tabel }}(1,66)$ dan sign $(0,000)<(0,05)$ berdasarkan hasil uji Koefesien determinasi R2 sebesar 62,8\%. Hal ini berarti kepemilikan manajerial kepemilikan institusional dan komite audit. secara bersama - sama memiliki pengaruh positif dan signifikan terhadap Nilai Perusahaan. hal ini dapat di buktikan pada uji F sebesar 38,231 pada perusahaan manufaktur yang terdaftar di Bursa Efek Indonesia 2015-2017.

Perhitungan nilai perusahaan menggunakan proksi PBV (price book value). Namun demikian perhitungan nilai perusahaan dapat dilakukan dengan menggunakan metode lainnya seperti Tobin's Q karena perhitungan nilai perusahaan tidak hanya menggunakan PBV. Mengingat hasil penelitian ini menunjukkan bahwa berpengaruh positif terhadap nilai perusahaan good corporate governance.
\end{abstract}

Kata kunci: Pengaruh Good Corporate Governance dan Nilai Perusahaan 


\section{PENDAHULUAN}

Berdirinya sebuah perusahaan harus memiliki tujuan yang jelas. Ada beberapa tujuan berdirinya sebuah perusahaan. Tujuan yang pertama adalah untuk mencapai keuntungan maksimal. Tujuan yang kedua adalah ingin memakmurkan pemilik perusahaan atau para pemilik saham. Sedangkan tujuan perusahaan yang ketiga adalah memaksimalkan nilai perusahaan yang tercermin pada harga saham. Ketiga tujuan perusahaan tersebut sebenarnya secara substansial tidak banyak berbeda. Nilai perusahaan dapat memberi kemakmuran kepada pemegang saham secara maksimum apabila harga saham meningkat. Semakin tinggi harga saham suatu perusahaan, semakin tinggi pula nilai perusahaan tersebut.

Good Corporate Governance (GCG) adalah Tata Kelola Perusahaan yang baik merupakan struktur dan mekanisme yang mengatur pengelolaan perusahaan sehingga menghasilkan nilai ekonomi jangka panjang yang berkesinambungan bagi para pemegang saham maupun pemangku kepentingan. Good Corporate Governance (GCG) dalam penelitian ini diukur dengan. Kepemilikan Manajerial, Kepemilikan Instutional dan Komite Audit, dimana ketiga hal ini memiliki pengaruh yang berbedabeda terhadap Nilai Perusahaan.

Nilai perusahaan pada dasarnya dapat diukur melalui beberapa aspek, salah satu ukuran atau proksi yang digunakan adalah price book value (PBV) atau membandingkan harga pasar per lembar saham dengan nilai buku per lembar saham. Penetapan price book value sebagai proksi.

Semakin besar rasio PBV semakin tinggi perusahaan dinilai oleh para pemodal relatif dibanding dengan dana yang ditanamkan di perusahaan. Disamping itu investor juga akan menilai prospek perusahaan di masa yang akan datang. Industri manufaktur merupakan salah satu industri yang memiliki prospek bagus dan menjanjikan untuk masa yang akan datang. Dengan adanya prospek bisnis yang menjanjikan maka akan menjadi daya tarik bagi para investor untuk menanamkan modalnya.

Munculnya masalah good corporate governance (GCG) karena adanya ketergantungan terhadap modal eksternal (ekuitas, modal pinjaman) yang digunakan untuk pembiayaan kegiatan perusahaan, investasi dan pertumbuhan perusahaan bahwa good corporate governance muncul sebagai akibat dari masalah keagenan yang timbul, dimana ada perilaku untuk mendatangkan keuntungan pribadi khususnya dari agen dengan merugikan kepentingan dari pihak lain (prinsipal). Hal ini terjadi karena adanya pemisahan kepentingan antara principal dan agent.

Tingkat kinerja keuangan ini biasanya tercermin dalam tingkat profitabilitas perusahaan. Dengan demikian, profitabilitas diduga dapat memediasi hubungan antara good corporate governance terhadap nilai perusahaan. Dari latar belakang tersebut, maka penulis tertarik untuk melakukan penelitian mengenai "Pengaruh Good Corporate Governance terhadap Nilai 
Perusahaan pada Perusahaan Manufaktur yang Terdaftar di Bursa Efek Indonesia Tahun 2015$2017 ”$.

\section{KAJIAN TEORITIS}

\section{Good Corporate Governance (GCG)}

Menurut Effendi (2016), tata kelola perusahaan atau (good corporate governance) merupakan suatu sistem yang dirancang untuk mengarahkan pengelolaan perusahaan secara professional berdasarkan prinsipprinsip transparansi, akuntabilitas, tanggung jawab, independen, kewajaran, dan kesetaraan.

Menurut Yustiavandana (2006) Corporate Governance sebagai sekumpulan hubungan antara pihak manajemen perusahaan, board, pemegang saham, dan pihak lain yang mempunyai kepentingan dengan perusahaan. Corporate Governance juga mensyaratkan adanya struktur perangkat untuk mencapai tujuan dan pengawasan atas kinerja. Corporate Governance yang baik dapat memberikan rangsangan bagi board dan manajemen untuk mencapai tujuan yang merupakan kepentingan perusahaan, dan pemegang saham harus memfasilitasi pengawasan yang efektif sehingga mendorong perusahaan menggunakan sumber daya yang lebih efisien.

Menurut FCGI (2011) pengertian good corporate governance adalah seperangkat peraturan yang menetapkan hubungan antara pemegang saham, pengurus, pihak kreditur, pemerintah, karyawan serta para pemegang kepentingan internal dan eksternal lainnya sehubungan dengan hak - hak dan kewajiban mereka, atau dengan kata lain sistem yang mengarahkan dan mengendalikan perusahaan

\section{Kepemilikan Manajerial}

Menurut Jensen dan Meckling (1976) kepemilikan manajerial dan kepemilikan institusional adalah dua mekanisme corporate governance utama yang membantu mengendalikan masalah keagenan (agency conflict). Agency Conflict adalah konflik kepentingan yang terjadi antara principal dan agent. Konflik keagenan ini dipengaruhi oleh adanya insider ownership. Insider ownership adalah pemilik perusahaan yang merangkap sebagai pengelola perusahaan. Peningkatan insider ownership akan mengakibatkan peningkatan nilai perusahaan.

Menurut Sulito, (2008), kepemilikan manajerial adalah semakin besar insider ownership, maka perbedaan kepentingan antara pemegang saham (pemilik) dengan pengelola perusahaan (manajemen) semakin kecil karena mereka akan bertindak dengan lebih hati - hati karena manajer juga ikut menanggung konsekuensi dari keputusan yang telah diambilnya. Apabila kepemilikan insider ownership kecil berarti hanya sedikit jumlah pemegang saham yang ikut terlibat dalam mengelola perusahaan sehingga semakin tinggi pula kemungkinan munculnya masalah keagenan. 
Kepemilikan manajerial menurut Rustendi dan Jimmi (2008) merupakan pemegang saham dari pihak manajemen yang secara aktif ikut dalam pengambilan keputusan perusahaan (direktur dan komisaris). Kepemilikan manajerial diukur dari jumlah presentase saham yang dimiliki manajer. Kepemilikan manajerial dipandang sebagai mekanisme kontrol yang tepat untuk mengurangi konflik keagenan yang menyebabkan agency cost yang tinggi.

\section{Kepemilikan Institusional}

Menurut Tarjo, (2008). Kepemilikan institusional merupakan saham perusahaan yang dimiliki oleh institusi atau lembaga seperti perusahaan asuransi, bank, perusahaan investasi, dan kepemilikan institusi lain.

Menurut Widiastuti, (2013), Kepemilikan Institusional merupakan kepemilikan saham oleh lembaga dari eksternal. Investor institusional tidak jarang menjadi mayoritas dalam kepemilikan saham. Hal tersebut dikarenakan para investor institusional memiliki sumber daya yang lebih besar daripada pemegang saham lainnya sehingga dianggap mampu melaksanakan mekanisme pengawasan yang baik. Keberadaan investor institusional dianggap mampu menjadi mekanisme monitoring yang efektif dalam setiap keputusan yang diambil oleh manajer.

Menurut Mukhtaruddin (2014). Kepemilikan institusional bertindak sebagai pihak pengendali manajer perusahaan. Semakin besar tingkat kepemilikan saham oleh lembaga, maka mekanisme kontrol manajemen kinerja akan lebih efektif. Dengan demikian, semakin efisien pemanfaatan aktiva perusahaan. Selain itu, keberadaan investor institusional dianggap mampu menjadi mekanisme monitoring yang efektif dalam setiap keputusan yang diambil oleh manajemen sehingga dengan adanya kepemilikan institusional akan mendorong peningkatan pengawasan yang lebih optimal.

Perdana dan Raharja (2014) menyebutkan bahwa perusahaan dengan kepemilikan institusional yang besar (lebih dari 5\%) mengindikasikan kemampuannya untuk memonitor manajemen. Pengaruh kepemilikan institusional sebagai agen monitoring ditekan melalui investasi mereka yang cukup besar dalam pasar modal. Monitoring tersebut tentunya akan menjamin kemakmuran bagi pemegang saham. Dalam hubungannya dengan fungsi monitor, investor institusional diyakini memiliki kemampuan untuk memonitor tindakan manajemen lebih baik dibandingkan investor individual.

\section{Komite Audit}

Menurut Wulandari, (2011). komite audit adalah mereview pengendalian internal perusahaan, memastikan kualitas laporan keuangan, dan meningkatkan efektivitas fungsi audit. Surya dan Yustiavandana (2006:145) menyebutkan bahwa komite audit adalah "organ tambahan yang diperlukan dalam pelaksanaan prinsip GCG”. Sedangkan berdasarkan keputusan ketua 
BAPEPAM - LK No: Kep - 643/BL/2012 pengertian dari komite audit adalah : Komite yang dibentuk oleh dan bertanggung jawab kepada dewan komisaris dalam membantu melaksanakan tugas dan fungsi dewan komisaris. Komite audit sedikitnya terdiri dari tiga orang berasal dari komisaris independen dan pihak dari luar emiten atau perusahaan publik dan diketuai oleh komisaris independen

Nilai Perusahaan

Menurut Moniaga (2013) menyebutkan bahwa nilai perusahaan merupakan persepsi investor terhadap perusahaan, yang sering dikaitkan dengan harga saham. Harga saham yang tinggi membuat nilai perusahaan juga tinggi. Harga saham merupakan harga yang terjadi pada saat saham di perdagangkan di pasar modal.

Sedangkan Sukirni (2012) menjelaskan bahwa nilai perusahaan merupakan kondisi tertentu yang telah dicapai oleh suatu perusahaan sebagai gambaran dari kepercayaan masyarakat terhadap perusahaan setelah melalui suatu proses kegiatan selama beberapa tahun, yaitu sejak perusahaan tersebut didirikan sampai dengan saat ini.

Meurut Nurlela dan Islahuddin (2008) nilai perusahaan dapat memberikan kemakmuran pemegang saham secara maksimum apabila harga saham perusahaan meningkat. Semakin tinggi harga saham, maka makin tinggi kemakmuran pemegang saham. Untuk mencapai nilai perusahaan umumnya para pemodal menyerahkan pengelolaannya kepada para professional. Para professional diposisikan sebagai manajer ataupun komisaris.

Suyanti (2010) Nilai perusahaan yang tinggi akan diikuti oleh tingginya kemakmuran pemegang saham. menyebutkan bahwa jika kemakmuran pemegang saham terjamin maka sudah pasti nilai perusahaan meningkat, dan kemakmuran pemegang saham ini akan dapat meningkat apabila harga saham yang dimilikinya juga meningkat. Dengan kata lain, bagi perusahaan yang menerbitkan saham di pasar modal, harga saham yang ditransaksikan di pasar modal merupakan indikator nilai perusahaan. Nilai perusahaan yang tinggi akan membuat pasar percaya tidak hanya pada kinerja perusahaan saat ini, namun juga pada prospek perusahaan di masa yang akan datang. 
Gambar 2.1

Kerangka pemikiran

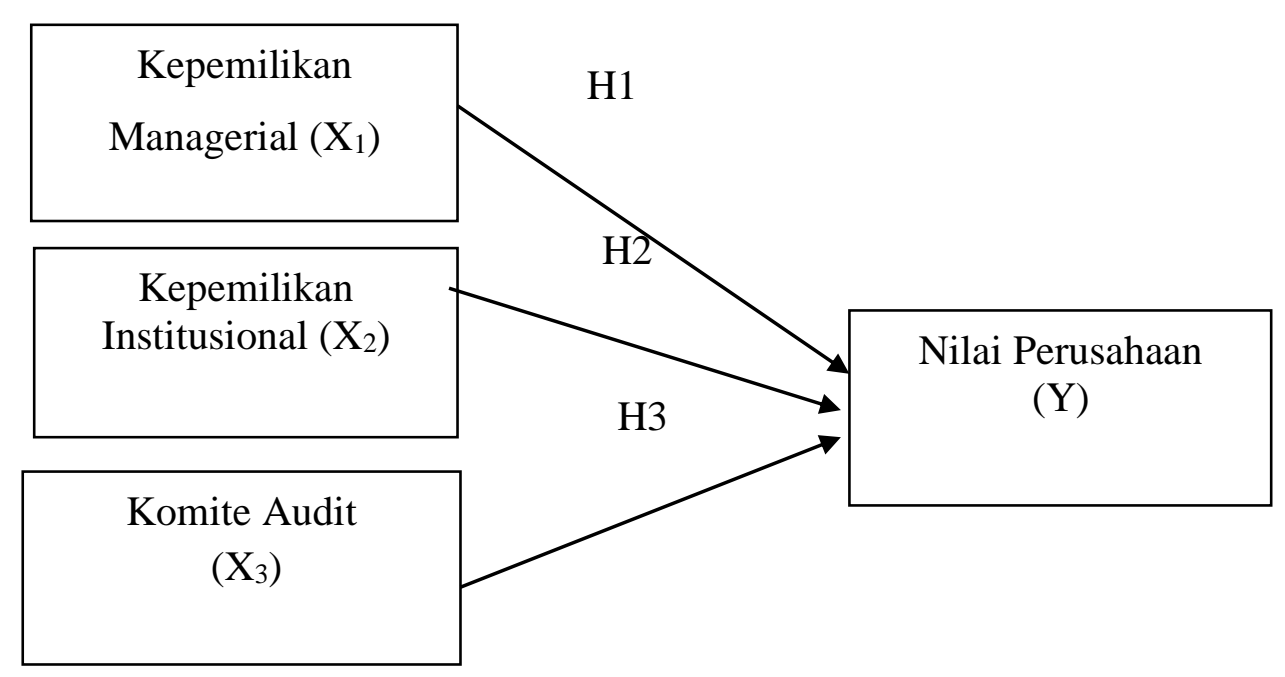

\section{METODOLOGI}

Populasi dalam penelitian ini adalah perusahaan manufaktur yang terdaftar di Bursa Efek Indonesia (BEI) tahun 2015-2017. Perusahaan yang menjadi populasi dalam penelitian ini adalah perusahaan manufaktur. Pengambilan sampel dalam penelitian ini dilakukan dengan menggunakan teknik purposive sampling yaitu pengambilan sampel berdasarkan pada kriteria tertentu dan didapatkan sampel sebanyak 72 perusahaan Manufaktur di BEI.

Variabel bebas (independen) dalam penelitian ini adalah modal yang diukur dalam penelitian ini adalah:

\section{Kepemilikan Manajerial $\left(\mathbf{X}_{1}\right)$}

Kepemilikan manajerial adalah jumlah kepemilikan saham oleh pihak manajemen dari seluruh modal saham perusahaan yang dikelola. Indikator yang digunakan untuk mengukur kepemilikan manajerial adalah persentase jumlah saham yang dimiliki pihak manajemen dari seluruh modal saham perusahaan yang beredar. Variabel ini diukur dengan cara mengidentifikasi pada daftar struktur kepemilikan terdapat nama yang masuk jajaran dewan direksi maupun dewan komisaris.

Rumus menghitung kepemilikan manajerial:

$$
\mathrm{KM}=\sum \text { Total saham yang dimiliki manajemen } \mathrm{X} 100 \%
$$

$\sum$ Jumlah saham beredar akhir tahun

Sumber: Thesarani (2016) 


\section{Kepemilikan Institusional $\left(\mathbf{X}_{2}\right)$}

Menurut Rosma (2007) dengan status kepemilikan ini, akan timbul anggapan bahwa pihak institusi pemilik akan memberi perhatian lebih terhadap pengelolan perusahaan, dan hal ini akan berpengaruh positif bagi perusahaan tersebut, baik dari segi peningkatan nilai perusahaan maupun peningkatan kinerja usaha. Kepemilikan institusional diproksi dengan menggunakan proporsi jumlah saham yang dimiliki oleh institusi, seperti pemerintah, institusi keuangan, institusi berbadan hukum, institusi luar negeri, dana perwalian, serta institusi lainnya pada akhir tahun. Kepemilikan institusional, diukur dari persentase kepemilikan saham oleh institusi.

Berikut rumus untuk mengukur Kepemilikan Institusional.

\begin{tabular}{|c|}
\hline $\mathrm{KI}=\sum$ Saham yang dimiliki institusi X \\
$\sum$ Total saham yang beredar \\
Sumber: Novalia, $(2016: 11)$
\end{tabular}

\section{Komite Audit ( $\left.\mathbf{X}_{3}\right)$}

Komite audit merupakan komite yang bertugas mengawasi dan mengelola pelaporan termasuk sistem penendalian internal dan penerapan prinsip akuntansi yang diterima umum, serta mengawasi proses secara keseluruhan Keberadaan komite audit merupakan variabel dummy dengan kriteria yaitu perusahaan yang memiliki komite audit dengan anggota yang seluruhnya berlatarbelakang akuntan akan mendapat nilai 1 sedangkan yang tidak memenuhi kriteria akan mendapat nilai 0. Variabel komite audit diukur dengan melihat jumlah anggota komite audit yang dimiliki perusahaan. Rumus menghitung komite audit:

\section{$\underline{\mathrm{KA}}=\ln \Sigma$ anggota komite audit}

Sumber: Shabibah (2017)

\section{Variabel terikat atau variabel dependen yaitu Nilai Perusahaan (Y)}

Variabel Dependen adalah tipe variabel yang dijelaskan atau dipengaruhi oleh variabel independen. Variabel dependen yang digunakan dalam penelitian ini adalah nilai perusahaan yang diukur dengan Tobin's Q yang dikembangkan oleh (Silveira dan Barros, 2007). Rasio Tobin's Q menunjukkan kesempatan bertumbuh perusahaan di masa yang akan datang melalui kebijakan investasinya. Tobin's Q dihitung dengan rumus:

Rumus Tobin's Q:

$$
\mathrm{Q}=\frac{(\mathrm{EMV}+\mathrm{D})}{(\mathrm{EBV}+\mathrm{D})}
$$

Sumber: (Sindhupdiptha dan Yasa, 2013)

Metode analisa data dalam penelitian ini adalah: Uji Asumsi Klasik. Tujuan pengujian asumsi klasik ini adalah untuk menguji dan mengetahui kelayakan atas model regresi yang 
digunakan dalam penelitian ini, pengujian meliputi: Uji Normalitas, Uji Multikolinieritas, Uji Heteroskedastisitas. Uji Signifikansi Parameter Individual (Uji Statistik t), Uji signifikansi Simultan (Uji statistik F), Koefisien Determinasi (R2), Analisis regresi linier berganda

$\mathrm{Y}$ $=a+b_{1} X_{1}+b_{2} X_{2}+b_{3} X_{3}+e$

Dimana:

Y

$=$ Nilai Perusahaan

$\mathrm{X}_{1} \quad=$ Kepemilikan Manajerial

$\mathrm{X}_{2} \quad=$ Kepemilikan Institusional

$\mathrm{X}_{3} \quad=$ Komite Audit

a Konstanta

$\mathrm{b}_{1}, \mathrm{~b}_{2}, \mathrm{~b}_{3}, \quad=$ Koefisien

\section{PEMBAHASAN}

Penelitian ini bertujuan untuk menganalisis kepemilikan manajerial kepemilikan Institusional komite audit terhadap nilai perusahaan pada perusahaan manufaktur yang terdaftar di Bursa Efek Indonesia di BEI Tahun 2015 - 2017, dalam penelitian ini menganalisis atatistik deskriptif yang berupa nilai rata-rata (mean), standar deviasi, nilai maksimum, dan nilai minimum.

Tabel 1

Hasil Uji Statistik Deskriptif

Descriptive Statistics

\begin{tabular}{|l|r|r|r|r|r|}
\hline & N & Minimum & Maximum & \multicolumn{1}{c|}{ Mean } & Std. Deviation \\
\hline Kepemilikan manajerial & 72 & 10.00 & 25.00 & 18.9722 & 3.50039 \\
Kepemilikan institusional & 72 & 12.00 & 25.00 & 17.4028 & 2.75098 \\
Komite audit & 72 & 11.00 & 25.00 & 19.8611 & 3.29449 \\
Nilai Perusahaan & 72 & 10.00 & 25.00 & 19.4167 & 3.14329 \\
& & & & & \\
\hline
\end{tabular}

Data penelitian ini sudah memenuhi uji asumsi klasik, sehingga layak menggunakan uji regresi linear. 


\section{Analisis regresi Linier Berganda}

Analisis regresi linier berganda pada dasarnya adalah studi mengenai ketergantungan variabel dependen (terikat) dengan satu atau lebih variabel independen, hasil dari uji regresi linier berganda adlah sebagai berikut:

Hasil Uji Regresi Linier Berganda
Coefficients $^{\mathbf{a}}$
\begin{tabular}{|l|r|r|r|}
\hline Model & \multicolumn{2}{|c|}{ Unstandardized Coefficients $^{*}$ Sig. } \\
\cline { 2 - 3 } & B & Std. Error & \\
\hline (Constant) & .994 & 1.755 & .573 \\
Kepemilikan manajerial & .304 & .079 & .000 \\
Kepemilikan institusional & .337 & .100 & .001 \\
Komite audit & .341 & .083 & .000 \\
\hline
\end{tabular}

a. Dependent Variable: Nilai Perusahaan

Sumber : Data sekunder yang diolah, 2019

Y Nilai Perusahaan $=0.994$ Kepemilikan Manajerial $0.304+$ Kepemilikan Institusional $0,337+$ Komite Audit 0,341

\section{Uji Koefisien Determinasi}

Uji ini digunakan untuk mengetahui seberapa besar pengaruh variabel bebas secara bersama-sama terhadap variabel terikat, penggunaan koefisien determinasi $\left(\mathrm{R}^{2}\right)$ adalah bias terhadap jumlah variabel independen (bebas) yang dimasukkan ke dalam model. Hasil dari koefisien determinasi sebagai berikut:

\section{Hasil Uji Koefisien Determinasi}

\begin{tabular}{|l|r|r|r|r|r|}
\hline Model & $\mathrm{R}$ & $\mathrm{R}$ Square & $\begin{array}{c}\text { Adjusted R } \\
\text { Square }\end{array}$ & $\begin{array}{c}\text { Std. Error of the } \\
\text { Estimate }\end{array}$ & Durbin-Watson \\
\hline 1 & $.792^{\mathrm{a}}$ & .628 & .611 & 1.95953 & 2.024 \\
\hline
\end{tabular}

a. Predictors: (Constant), Komite audit, Kepemilikan institusional, Kepemilikan manajerial

b. Dependent Variable: Nilai Perusahaan

Sumber : Data sekunder yang diolah, 2019

Koefisien determinasi ( $\mathrm{R}$ Square) sebesar 0,628. Hal ini berarti bahwa variabel Kepemilikan Manajerial Kepemilikan Institusional dan Komite Audit mempunyai peranan $62,8 \%$. Sedangkan sisanya sebesar $37.2 \%(100 \%$ - 37.2\%) dijelaskan oleh variabel lain yang mempengaruhi Nilai perusahaan.

\section{Hipotesis}

\section{a. Uji Kesesuaian Model}

Uji statistik F pada dasarnya menunjukkan apakah semua variabel independen atau bebas yang dimasukkan dalam model mempunyai pengaruh secara bersama-sama terhadap variabel dependen/terikat. 
Berikut adalah hasil dari uji $\mathrm{F}$

ANOVA $^{\mathrm{a}}$

\begin{tabular}{|l|r|r|r|r|r|}
\hline Model & Sum of Squares & \multicolumn{1}{|c|}{ df } & Mean Square & F & Sig. \\
\hline Regression & 440.396 & 3 & 146.799 & 38.231 & $.000^{\mathrm{b}}$ \\
1 Residual & 261.104 & 68 & 3.840 & & \\
Total & 701.500 & 71 & & & \\
\hline
\end{tabular}

a. Dependent Variable: Nilai Perusahaan

b. Predictors: (Constant), Komite audit, Kepemilikan institusional, Kepemilikan manajerial

Berdasarkan tabel 4.7 nilai $\mathrm{F}$ hitung sebesar 38,231 dengan tingkat signifikansi $0.00<$ 0,05. Sehingga dapat disimpulkan bahwa model tersebut merupakan model yang fit.

b. Uji Hipotesis Parsial Dengan T-test

Uji t digunakan untuk mengetahui sejauh mana variabel bebas berpengaruh secara parsial terhadap variabel terikat, dengan tingkat kesalahan $5 \%$.

Hasil Uji Hipotesis Parsial Dengan t-test

Coefficients $^{\mathrm{a}}$

\begin{tabular}{|l|r|r|}
\hline Model & \multicolumn{1}{c|}{$\mathrm{t}$} & \multicolumn{1}{c|}{ Sig. } \\
\hline (Constant) & .567 & .573 \\
Kepemilikan manajerial & 3.847 & .000 \\
Kepemilikan institusional & 3.375 & .001 \\
Komite audit & 4.110 & .000 \\
\hline
\end{tabular}

a. Pengujian hipotesis 1

a. Dependent Variable: Nilai Perusahaan

Variabel Kepemilikan Manajerial $\left(\mathrm{X}_{1}\right)$, nilai t-hitung adalah sebesar 3.847 dan t-tabel $(1,66)$ nilai probabilitas lebih kecil dari 0,05 yaitu sebesar 0,000. Hal ini menunjukkan bahwa variabel Kepemilikan Manajerial, berpengaruh signifikan terhadap Nilai Perusahaan dan mempunyai arah hubungan positif, sehingga tingginya Kepemilikan Manajerial akan mempengaruhi Nilai Perusahaan pada Sektor Manufaktur yang terdaftar di Bursa Efek Indonesia tahun 2015 - 2017.

Kepemilikan Manajerial berpengaruh terhadap Nilai Perusahaan. Hasil penelitian ini sejalan dengan penelitian yang dilakukan oleh Defi Kurnia Julianti (2015), menggunakan sampel pada perusahaan manufaktur di BEI selama periode 3 tahun menemukan bahwa Kepemilikan Manajerial berpengaruh terhadap Nilai Perusahaan perusahaan.

b. Pengujian hipotesis 2

Variabel Kepemilikan Institusional $\left(\mathrm{X}_{2}\right)$, nilai t-hitung adalah sebesar 3.375 dan t-tabel $(1,66)$ nilai probabilitas lebih besar dari 0,05 yaitu sebesar 0,001. Hal ini menunjukkan bahwa variabel Kepemilikan Institusional, berpengaruh signifikan terhadap Nilai Perusahaan dan mempunyai arah hubungan positif, sehingga tingginya Kepemilikan Institusional akan mempengaruhi kenaikan Nilai Perusahaan di Bursa Efek Indonesia tahun 2015 - 2017. 
Kepemilikan Institusional pada penelitian ini memiliki pengaruh signifikan terhadap Nilai Perusahaan. Hal ini sesuai dengan penelitian yang dilakukan oleh Reny Dyah Retno M. Denies Priantinah (2013) yang menemukan hubungan positif antara Kepemilikan Institusional dengan Nilai Perusahaan. Kepemilikan institusional merupakan saham perusahaan yang dimiliki oleh institusi atau lembaga seperti perusahaan asuransi, bank, perusahaan investasi, dan kepemilikan institusi lain

c. Pengujian hipotesis 3

Variabel Komite Audit $\left(\mathrm{X}_{3}\right)$, nilai t-hitung adalah sebesar 4.110 dan t-tabel $(1,66)$ nilai probabilitas lebih besar dari 0,05 yaitu sebesar 0,000. Hal ini menunjukkan bahwa variabel Komite Audit, berpengaruh signifikan terhadap Nilai Perusahaan dan mempunyai arah hubungan positif, sehingga tingginya Komite Audit akan mempengaruhi kenaikan Nilai Perusahaan pada perusahaan Sektor Manufaktur yang terdaftar di Bursa Efek Indonesia tahun $2015-2017$.

Komite Audit pada penelitian ini memiliki pengaruh signifikan terhadap Nilai Perusahaan. Hal ini sesuai dengan penelitian yang dilakukan oleh Reny Dyah Retno M. Denies Priantinah (2013) yang menemukan hubungan positif antara Komite Audit dengan Nilai Perusahaan. komite audit adalah mereview pengendalian internal perusahaan, memastikan kualitas laporan keuangan, dan meningkatkan efektivitas fungsi audit

\section{KESIMPULAN}

1. Kepemilikan Manajerial berpengaruh signifikan terhadap Nilai Perusahaan. Dengan demikian hipotesis 1 dalam penelitian ini diterima.

2. Kepemilikan Institusional berpengaruh signifikan terhadap Nilai Perusahaan. Dengan demikian hipotesis 2 dalam penelitian ini diterima.

3. Komite Audit berpengaruh signifikan terhadap Nilai Perusahaan. Dengan demikian hipotesis 3 dalam penelitian ini diterima. 


\section{DAFTAR PUSTAKA}

Aloy Niresh, J. dan Alferd, M. 2014. "The Association between Economic Value Added, Market Value Added and Leverage".International Journal of Business and Management; Vol. 9, No. 10; (September 2014) ,Hal.

126 . ISSN 1833-3850 E-ISSN 1833-8119.

Arikunto, Suharsimi (2010). Prosedur Penelitian Suatu Pendekatan Praktik, Jakarta: PT. Rineka Cipta

Ariyanti Resti (2015). "Pengaruh Debt To Equity Ratio, Return On Equity, dan Economic Value Added Terhadap Market Value Added Perusahaan Publik Yang Termasuk Dalam Jakarta Islamic Index Tahun 2009-2013”. Journal Business UIN Sunan Kalijaga. Vol. 9, No. 1.

Baridwan,Zaki. 2005. Intermediate Accounting. Yogyakarta: BPFE-Yogyakarta

Dahlan, Siamat (2001). Manajemen lembaga keuangan. Lembaga Penerbit Universitas Indonesia.

Duane, VE. (2015). “ Pengaruh Current Ratio (CR), Debt To Equity Ratio (DER), Return on Asset (ROA) dan Economic Value Added (EVA) Terhadap Market Value Added (MVA) Pada Perusahaan Perbankan Yang Terdaftar Dalam Indeks LQ45 Periode 2008 2012”. e-journal Politeknik Pos Indonesia. Vol.2, No.1.

Harahap, Sofyan. 2008. Analisis Kritis atas Laporan Keuangan. Jakarta: Raja Grafindo Persada.

Helfert, Erich A. 1996. Teknik Analisis Laporan Keuangan. Jakarta: Erlangga. Kasmir,. 2008. Analisis Laporan Keuangan . Jakarta: Rajawali Pers.

Kieso, Donald E (2008). Akuntansi Intermediate edisi 12 Jilid 1, Jakarta :Erlangga

Mertayasa, Cipta and Suwendra (2014). "Pengaruh Return On Asset Dan Ecconomic Value Added Terhadap Market Value Added Pada Perusahaan Perbankan Go Public". e-journal Bisma Universitas Pendidikan Ganesha Jurusan Manajemen (Volume 2 Tahun 2014)

Panigrahi, Srikant. (2014). "Investigating Relationship between EVA and MVA of Selected Construction Companies in Malaysia". The International Joumal Of Business and Managamen, Vol. 2, Issue : 6 ( Juni 2014), Hal. 136-140 . ISSN 2321-8916

Prawironegoro, Darsono. (2010). Manajemen Keuangan Edisi Pertama. Nusantara Consulting, Jakarta.

Purnamaningsih, Dita. (2014). "Pengaruh Return On Asset,Struktur Modal,Price To Book Value dan Good Corporate Governance Pada Return Saham". Vol. 9, No. 1,; (Februari 2014), Hal. 1-161 .ISSN: 2302-8556E

Sathya, M. 2012. "Market Value Addition As The Most Significant Measure Of Financial Performance". Indian Journal Of Applied Research, Vol.1,Issue : 12 (September 2012), Hal.23 . ISSN - 2249- 555X. 
Sjahrial, Dermawan. (2010). Manajemen Keuangan Edisi Keempat. Mitra Wacana Media, Jakarta.

Suwardjono. 2010. Teori Akuntansi : Perekayasaan Laporan Keuangan edisi ketiga. Yogyakarta: BPFE.

Tandelilin, Eduardus. 2010. Portofolio dan Investasi - Teori dan Praktek. Kanisius: Yogyakarta

Wild, J J.; Subramanyam,K.R.; dan Hasley,Robert F. 2005. Analisis Laporan edisi kedelapan buku satu. Jakarta: Salemba Empat.

Wild, J J.; Subramanyam,K.R.; dan Hasley,Robert F. 2005. Analisis Laporan edisi kedelapan buku dua. Jakarta: Salemba Empat. 